\title{
Questioning Participation and Display Practices in Fine Arts Museums
}

Cuestionando la participación y las formas de exhibir en museos de arte

\section{Nicole Moolhuijsen}

\section{(2) OpenEdition \\ 12 Journals}

Electronic version

URL: http://journals.openedition.org/iss/630

DOI: $10.4000 /$ iss. 630

ISSN: 2306-4161

Publisher

ICOM - International Council of Museums

\section{Printed version}

Date of publication: 1 June 2015

Number of pages: 191-202

ISSN: 2309-1290

\section{Electronic reference}

Nicole Moolhuijsen, « Questioning Participation and Display Practices in Fine Arts Museums »,

ICOFOM Study Series [Online], 43a | 2015, Online since 06 February 2018, connection on 01 May 2019. URL : http://journals.openedition.org/iss/630 ; DOI : 10.4000/iss.630 


\title{
Questioning Participation and Display Practices in Fine Arts Museums
}

\author{
Nicole Moolhuijsen \\ ICOM - Italy
}

\begin{abstract}
Over the last decades, the relationship between the museum and the public has been undergoing a profound transformation, in which the stature of the latter has been constantly rising, contrasting with the foundation of the traditional model of the museum where the voice of the public was not heard (Weil, 1997, 2002; Hooper-Greenhill, 2000; Lang, 2006; Sandell, 2012). The surge of participatory practices in the museum sector is compelling evidence of this composite change, and the relative literature is becoming richer and more sophisticated. It is not possible to examine the exact impact of this trend, as it generates diverse outcomes depending on the context, the nature of the institution and its stakeholders. Moreover, within the museological debate, professionals disagree in deciding to what extent their institutions' agenda should actively take into account the voice of the public (O'Brien, 2013). Nonetheless, even though there are still blurred edges amongst the various lines of thought, there is a widespread consensus that museums as cultural institutions "in the service of society and its development" (ICOM, 2007) should strive to provide meaningful experiences to the widest possible audience and improve the quality of the relationship they have with their publics.
\end{abstract}

In practice participation can assume various forms, nevertheless the backbone of its conceptualization relates to the idea of 'shared authority', 'audience empowerment' and 'democratization', which results in the transformation of the museum into a platform where diverse and conflicting voices and awareness of professionals and audiences can find expression (Hutchison, 2013; Museum Association, 2012; Simon, 2010). This museological model contrasts with the major current trends of display practices in European art institutions for collections of Old Masters and historical paintings. In this domain, artworks are primarily presented under art historical rhetoric that perpetuates a hierarchical and monovocal structure of knowledge. This genre of display tends to be developed by museum professionals only, and the information presented is generally art historical. As a result, non-specialist audiences struggle to access displays, and the space left for meaningful interaction and personal interpretation is little.

From these premises, this essay will address the issue of 'participation' by looking at the ways in which knowledge and information are constructed, interpreted and reproduced in displays featuring Fine Art, questioning directly the epistemological status of the art museum and the pillars upon which it is based, most evidently the discipline of art history, the role of curators and of audiences. The first part of the essay will discuss objects' ontology and artworks' multilayered structure of significance, in order to open up the possibility to look at them beyond their disciplinary meanings. This choice may appear anachronistic in regard to the international debate, as the polysemic nature of material culture is acknowledged in literature since the contribution of postmodern theories and critical studies; however, this is considered a necessary precursor to discuss participation with reference to the display of Old Masters and Fine 
Art, as the epistemological foundation of their interpretative framework is rarely questioned (Whitehead, 2012).

The paper will explain the difficulties of adapting the arguments posed by postmodern theories and participatory museological trends to approach the interpretation of Fine Art, and on the reluctance of curators and art historians to consider the effects of these considerations on the epistemology of their discipline. It will be argued that the entanglement of art historical theories and the nature of museum institutions, as well as fear of losing scholarship and status, are motivating factors of this reluctance. For this reason, the essay will review displays that, whilst respecting the historical values of objects and the expertise of diverse museum professionals, value and voice peoples' understanding of objects.

The aim of the paper is to show that participatory displays of Old Masters and paintings are based on their conception as powerful carriers of meaning able to disclose socio-cultural aspects of their history, which if interpreted in the museum from multiple perspectives can give a voice to personal interpretations and a new life in the present.

As the contribution arises from research conducted in the United Kingdom, all case studies discussed will be of British provenance. Although it could be argued that it restrains the scope of the paper, the international character of the bibliography suggests that the embrace of participatory display practices in Fine Art museums may be a necessity and a reality not only for museums in the UK.

\title{
Museological negotiations: knowledge of objects
}

\begin{abstract}
Most themes used in art galleries are very predictable the artist and his (sometimes her) work, an art-historical school or period, a style. This type of approach requires the visitor or potential visitor to recognise and value significant artists, styles, art-historical periods and schools (Hooper-Greenhill, 1994, pp. 262-263).
\end{abstract}

In writing his cultural history on the invention of art, Larry Shinner (2001) positions the development of the Fine Arts as an art-historical category at the end of the $18^{\text {th }}$ century, describing how this type of material culture became enshrined with a higher status in contrast to other types of objects and considered sufficiently valuable of appreciation because of its aesthetic beauty. Christofer Whitehead (2009) and Colin Trodd (2003) noted how the development of museums' displays and their language in the domain of art history was entwined with the construction of disciplines at the start of the $19^{\text {th }}$ century, projecting therefore their knowledge schemes and hierarchies of values on museum's walls. Though writing from a British perspective and frequently referring to the case of the National Gallery in their studes, their considerations can apply to the wider European context (Conforti, 1993).

The dispersion of material culture across Europe after the French Revolution. and its reorganisation with the subsequent birth of the "modern museum", was specifically intended to reflect and advance art historical studies, as well as to create and reinforce national pride and myths. Artworks of international importance left their location of origin on the road to the Louvre, whereas other objects became grouped into national and regional museums (Barbieri, 2004). 
Though this rigid division has slightly changed with the suppression of religious orders and the abolition of Napoleons' declarations, these ideas are still visible across the organisation of European museums, as the development of art history coincides with that of the art museum, intended in the Western and modern sense.

The display of artworks from the position of art history strengthened the consolidation of disciplinary visual discourses, as the quote by Hooper-Greenhill (1994) suggests. In fact, notwithstanding the current recognition that museum objects, as polysemic entities, can be interpreted from multiple points of view and be used to tell diverse stories, many European art museums still exhibit artworks from the perspective of art history, perceiving their role as that of making art historical narratives visible on museums' walls. Do artworks then have no other value, significance or story to tell beyond their art historical one?

This inquiry is interlinked with theories of knowledge and interrogates the problematic notion of the meaning of artworks beyond their disciplinary significance. During the poststructuralist era, philosopher Michel Foucault (1975) has questioned the epistemological basis of the disciplines and their modalities of knowledge construction and transmission. Foucault was suspicious of statements of 'Truths', intending the concept as an assessment implying universal validity, not as the opposite of fault (Rabinov, 1991). According to him, disciplines such as art history dispense truths (in the shape of knowledge) but their schemes of knowledge production are underpinned by values that are contingent to individuals, time, places and politics.

Poststructuralist and postmodern authors have shown how disciplinary knowledge is changeable and not absolute, having a strong impact on the way museum professionals understand and interpret material culture (Porter, 1991). Eilean Hooper-Greenhill's Museums and the Shaping of Knowledge (1992), the publication of her doctoral research (1988), manifests the compelling influence of Foucault's theories in the museum sector. In writing her 'effective history' of museums, she insightfully explained how artworks have assumed different meanings throughout history. Hooper-Greenhill's (1988) case study is a painting of a 'Madonna and Child' and she showed how the same material thing was displayed as a magical item giving protection in the 'Medici Palace'; as a cosmological picture representing the "hierarchical structure of the world" (p. 339) in 'the cabinet of the word'; as an unfaithful depiction of nature in the Repository of the Royal Society; and, ultimately, as a work of art showing the characteristics and influences of a style in the modern museum (pp. 334-336). She demonstrated how the same artwork has embodied different values and represented various concepts depending on the mentality and the culture of the people in time. Regardless, their diverse understandings were presented as facts in each context. Hooper-Greenhill (1988) concludes that "material things have no essential identity" (p.341).

In addition to this, Hooper-Greenhill's reconstruction outlined how Old Masters and historical paintings have acquired many stories and significances in time, because of their composite history and intimate relationship with the society that produced them and through which they traveled. Nevertheless, the status that the art historical significance of Old Masters and historical paintings in the Western canon overwhelms non-specialist stories and matters behind the 
objects and considered as the most valuable, is presented as the only meaning in the museum.

This recognition led museologists to discuss the "role that the object plays in defining what the museum should be about" (Witcomb, 1997, p. 384) hardly questioning disciplinary presentations of collections. In perceiving exhibits as mediums transmitting an official culture, practitioners have prompted their renewal and revisited the information they were communicating. This reasoning opened up the possibility to present collections telling stories beyond their disciplinary significances and to involve the audience in the processes of selection and presentation of objects (Stam, 2005). This subversion of hierarchies has encountered resistance in the museum workforce, especially among professionals with expertise in the content of the collection, such as curators (Mason et al., 2013). Josie Appleton's (2007) line of thought exemplifies this position:

\begin{abstract}
Advocates of the people-centered museum argue that collections have no intrinsic value anyway. Their value lies instead in their relationship to The People. [...] Expertise in objects, it seems, is just one of the many functions of the new curator. Underlying all these changes is the declining authority of scholarship itself. The advance of cultural relativism throughout the Western academic system [has] shattered the belief among scholars that there was anything intrinsically valuable held by the museum, or that their understanding of objects [is] any more valuable than anybody else. [...] If scholarship in the museum is neglected, our knowledge will suffer (p.119 - 120).
\end{abstract}

New museological and participatory trends have been criticized in their philosophy because approaching the meaning of an object in non-disciplinary ways, and involving the audience in its interpretation, are claimed to circumvent its 'real' significance and to underestimate professionals' expertise. Reckoning the epistemological relativity of the discipline sustaining the curatorial profession is still a problematic point, as it questions curators' absolute control in the production of contents.

\title{
An epistemological alternative: empowering the audience
}

The debate surrounding the role of the discipline and curatorial expertise in the display of collections encounters a fracture, both in the intellectual debate and in practice (Meszaros, 2011). On the one side, professionals who acknowledge poststructuralist, postmodern theories and new museology believe that museums impose knowledge from objects and that artworks in collections "do not have meanings per se" (Herrero, 2007, p. 142). Therefore they even develop displays bypassing disciplinary discourses. On the other side, those who reject these views encourage more traditional interpretations, arguing that in trying to be significant to a wider audience museums are losing their expertise (Appleton, 2007). The paper will now analyze the display at the Kelvingrove Art Gallery in Glasgow, in order to propose an alternative epistemological approach on this dichotomy position.

The interpretation scheme adopted to refurbish the Kelvingrove Art Gallery is built on a framework that promotes work across disciplines, where artworks are used to tell the stories that arise from an 
integration of knowledge of objects, visitors, staff and society (O'Neill, 2006). The display moves away from the idea of knowledge as a "definitive body of facts" (O'Neill, 2006, p. 112), where objects are testimonies of disciplinary discourses. By contrast, it contextualizes artworks around themes and panels pose questions related to basic human questions of identity, gender roles, materials, life, death and myth that are linked either to the collection or to people's cultural and personal backgrounds. Visitors are in this way engaged in a continuous process of discovery, both of the objects and themselves, that validates their own understanding encouraging curiosity (O'Neill, 2007). Throughout the refurbishment process, curators researched a number of stories that were linked to the objects; whilst consulting professionals with expertise in education, design, visitor studies, interpretation and members of the public, the most effective ones were selected. The continuously changing displays, conceived as multilayered narratives that can suit the interests of multiple audiences, have been developed by an interdisciplinary team of professionals in participation with visitors, all conjointly contributing with their specific expertise to the project.

The Kelvingrove Art Gallery does make a case for the value of an object's multi-layered structure of significance, reinforcing poststructuralist philosopher Jaques Derrida's (1972) assertion that the meaning of objects can never be located in a 'fixed system'. This is far from being an attempt to say that artworks have any innate, disciplinary or independent meanings but only ones attributed by external factors. This latter position has historically prompted curators to propose even more conservative displays, in order to reinforce the idea that the art historical significance of an object is its first and real one. On the contrary, the poststructuralist argumentation and the concept of the polysemic nature of objects, should be regarded as an invitation to look at artworks from multiple perspectives and to accept that they can have various meanings and be used to tell diverse stories.

A new epistemology of museums that links "formal, informal, academic, experiential and intuitive knowledge of objects, ourselves, visitors and society into a coherent framework" can foreground audience participation on two levels: firstly, by involving the public in the processes of display through consultation at every stage, from concept to evaluation; ultimately, by empowering the audience to actively construct their own personally relevant meanings from artworks in relation to their personal experiences.

\section{Co-production of contents}

Another perspective to discuss participation in the museum is looking at the ways in which institutions engage with their audiences in the process of exhibition making, whereby successful participatory projects aim to share authority fostering the public's active involvement in the production of the contents for displays (Simon, 2010).

Under the stream of the new museology, practitioners have integrated different and conflicting points of view in the exhibits including the audience ones - in order to dismantle authority and paradigms of presumed objectivity (Stam, 2005). Institutions such as the Natural History Museum at the University of Parma have involved the community to rewrite African objects' stories, overcoming 
Eurocentric interpretative approaches. There, two collections of African objects are used to tell the stories of the people who used them, their cultures and their beliefs, rather than being exhibited as merely evidence of disciplinary discourses (lervolino, 2013). Such types of initiative are carried out in different genres of museums, particularly those of history, anthropology and art (principally nonwestern), where the call of postcolonial and feminist academics to revise narratives and art historical canons has been accommodated (Hooper-Greenhill, 2000; Karp, 1992; Messenger, 1999; Tucker, 1992). This reframing is manifested in Stephen Weil's (1990) words as a shift of focus from the object 'isness' to its 'aboutness'.

Whilst recent studies point out the complexity behind participation and community engagement, it should be noted - as the focus here is on European artworks exhibited in western institutions - that thinking about the issue of 'voice' assumes different nuances if compared to the mainstream of postmodern literature, which is "understandably dominated by discussions of colonial contexts" (Mason, 2013, p. 166) and museum histories. In fact, when reviewing the significance of objects in the context of ethnographic, social and local history collections, expertise is given to the public because they may have inherited cultural capital that can "reveal new information" (Collections Trust, 2009, p. 5) about artefacts. The public's 'other voices' are respected because they are linked to the objects' and if integrated in displays can provide new points of entry and help a wider audience to make meaning of them (Mason, 2013). On the contrary, sharing notions about the content of a work of art requires a degree of specialist knowledge that still can be traced back to the discipline of art history, remaining therefore constrained to disciplinary fields and academic environments. This recognition sheds light on the social background to the resistance of democratizing art museums as opposed to other type of institutions. In fact, as Pierre Bordieu (1993) and others discussed, the attribution of value in the context of art is the privilege of players who retain the cultural capital (in terms of knowledge, position and education) to determine what can count as art. Neither the artists, nor ordinary people lacking art education, have the status to be involved in objects' interpretation process so that it their values as much as in the context of ethnographic social history collections.

It stands out that it is not very clear how the contribution of new museological trends regarding the 'aboutness' of objects fits within the comprehension of Old Masters. As a consequence, democratizing the processes of exhibition making in the domain of traditional art is still problematic and implies two main challenges. The first one relates to the difficulties of finding correlations between artworks' content and visitors' non-specialist knowledge. The other one calls into question the long-standing issue of threatening museum's scholarship and professional expertise.

The paper will now look at the display at the Laing Art Gallery at Newcastle, as it provides insight about how to address these problems.

The current layout is the result of a project carried out by the International Centre for Cultural and Heritage Studies in collaboration with the museum and Newcastle University. The museum's collection of historical paintings mostly depict the regional landscape, therefore the team of researchers behind the project adopted the concept of identity connected to the land as a trigger to investigate people's 
relationship with the territory and to share authority when developing the displays. Whilst panels written by the museum's staff provide knowledge about the history of the region and its artists, interactive devices play audiovisual recordings of local people telling the stories of how they perceive(d) the places shown in the pictures. Their personal memories become a source of knowledge and, offered to visitors to make meaning of the artworks and places, encourage personal associations with the stories narrated and the subjects of the collection.

The exhibit reframes "what is traditionally classed as art history within a broader concept of visual culture" (Mason, 2013, p. 167), allowing us to respect the objects' specialist value and to look at them both from an art historical and socio-cultural perspective. This strategy has opened up the possibility of giving a voice to people's personal memories and to make "visible different types of knowledge usually held apart intellectually and physically in museums and galleries" (Mason, 2013, p.166).

Throughout the project, curators did not lose their expertise in favor of participants; all voices are included and operate at diverse levels of engagement. The whole display works as a platform, where "different knowledge resonates against one other, to disrupt conventional boundaries" (Mason, 2013, p. 167). This was the result of a "complex series of negotiations" (Mason, 2013, p. 165) between the parties, facilitated and encouraged by other professionals such as interpreters, mediators and researchers.

\section{What does this painting mean to me?}

Participatory practices aim to hearten people's sense of ownership of cultural heritage, by encouraging them to interpret collections in personally meaningful ways, imposing new values on objects. This museological model, which has its source in constructivist learning theories and the conceptualisation of knowledge as a social construct, has prompted institutions to foster visitors to make interpersonal connections with the objects on display, to construct their own meanings and to share them (Simon, 2010). As synthesised by Nina Simon (2010) in The Participatory Museum, artefacts are 'social objects', which should be used therefore to spark conversation around them. Even if museums with art historical collections have undertaken projects in this direction, this attitude tends to be taken forward primarily by educational and outreach departments, lacking inputs at interpretative levels in the displays. Moreover, even if institutions such as the Laing Art Gallery in Newcastle have worked with members of the public to reproduce their stories in the museum, these engage primarily with the paintings' visible subjects without accounting for their history and past 'social life'.

The analysis will now consider the display of two paintings, Sirens and Ulysses at Manchester Art Gallery and Godiva at the Herbert Art Gallery \& Museum in Coventry, to provide diverse positions on this topic.

At the Herbert, the artwork frames a moment in time of Godiva's procession through the city of Coventry, and its exhibit investigates the socio-cultural significance of the artwork's history. By employing a storytelling approach, analogies are made between the socio- 
cultural context of the painting's production and that of the present, and stories are told about its use and interpretation throughout history. Moreover, as the story of Godiva is part of the identity of local visitors, their personal understanding of the object is also validated through an interactive display: what does Godiva mean to me? A screen presents recordings from local citizens who were involved in the display project and tell their sensations according to their personal, academic, cultural or social backgrounds, and visitors can add their views. Moreover, the display integrates stories with a similar theme from around the world, in order to encourage visitors with diverse cultural backgrounds to make meaning of the painting in relation to their own cultures and go beyond the visible subject.

At Manchester Art Gallery, the masterpiece Sirens and Ulysses by William Etty is on permanent display. The text panel of the painting tells the story of the subjects depicted, while an interactive screen investigates the history of its restoration. The artwork went through several processes of interventive conservation that included the overpainting of portions of the canvas resulting in a major alteration of its physical appearance. The gallery's staff decided then to remove the layers of overpaint applied by the previous conservators and, controversially, to reconstruct the original appearance of the painting. The interactive screen asks: is it still the artist's own work? The restoration process took place in an open space in the gallery, where visitors were asked to comment during its development. They answered questions such as: should we be doing this? How far should we go? Their comments are still visible on the screen and the debate is ongoing. Through the screen visitors can learn how a process of restoration can function, consider and express opinions about the ethical implications of conservation, and navigate behind the scenes of a museum.

Both museums look at objects as living material culture storing social information and use artworks to disclose knowledge related to the social culture of their history. This trigger allows objects to be set in wider interpretative frameworks and encourages the audience to construct, reproduce and share their understandings in the museum, which accounting for the artworks' history imposes new overall value on the object.

\section{Conclusions}

Since the contribution of postmodern and poststructuralist theories, single disciplines are no longer seen as able to unravel the whole significance of collections. This acknowledgment, combined with the need to support visitors without specialist knowledge to access displays, promoted museum professionals under the stream of the new museology to recontextualise "objects within the realm of ideas" (Conforti, 1995, p. 340) and to display artifacts for the significances they can have for the public and for their 'aboutness'. In order to overcome the complication of adjusting these arguments to the presentation of Old Masters and historical paintings, the paper proposed frameworks of interpretation based on the valorization of the objects' socio-cultural history and multilayered structure of significance. As a consequence, the paper discussed audience participation in three aspects.

All the displays propounded that participation in museums starts by encouraging the audience to construct personally relevant 
significance from displays. The Kelvingrove Art Gallery integrated knowledge of objects with knowledge of visitors and displayed artworks around universal themes, where interrogative panels motivate the audience to reflect upon their own lived experience and relate it to the artworks' content. Likewise, the Laing Art Gallery and the Herbert, through the interpretation by other groups of visitors of the artworks' visible subjects or socio-cultural history, encourage personal engagement with the objects on display.

A second aspect of participation has looked at audience inclusion in the processes of exhibition making. Both the Laing Art Gallery and the Herbert worked with groups of participants during their redisplay projects. The public involvement, facilitated by researchers and interpretation experts, resulted in the development of design platforms that makes their voice visible and audible in the museum, providing tools for new visitors to engage with each other and objects. Also the Kelvingrove Art Gallery, through consultation, involved groups of audience to evaluate their refurbishment process at every stage.

Lastly, participation has been discussed in terms of 'audience empowerment', that is to say giving the public the opportunity to reproduce their understanding of objects in the museum during the visit. Manchester Museum has moved forward the idea that museums should promote public understanding of the activities that take place behind their walls, allowing the audience to express opinions and make decisions. Through the interactive display, visitors can look at the painting from the museum's point of view, which results in a frame of interpretation and intentionally provokes their reactions. Similarly, the interactive screen at the Herbert Museum explicitly asks the public to share their understanding of the object and to impose a new value on it.

It stands out that these strategies have overturned hierarchies of knowledge and value that have long underpinned canonical presentations of artworks in traditional art museums, suggesting that participative museology does not indicate a series of interactive design tools or engaging activities, but a change in the way museums look at what is their heart, that is to say knowledge of collections and hierarchies between professionals and audiences.

This consideration suggests that, in the processes of selection and presentation of objects, the expertise of curators should be placed alongside that of professionals with multidisciplinary knowledge within the museum and include audiences from concept to display. Visitor studies, facilitators and interpretation specialists will play a fundamental role, in order to find points of contact between objects and visitors and complement them into accessible and participative interpretative frameworks, while working closely with the public at every stage. As a consequence, the traditional processes of exhibition making will be inverted. Museum professionals will have to study their public, find out their characteristics and work out how they can relate to the collections. Far from having universal formulas to apply, participatory practices are ad hoc projects arising from the knowledge of objects and visitors and through continuous exchanges between diverse practitioners and audiences.

In addition to this, it should be noted that sharing authority in the museum does not imply a total shift of power from curators to the audience, but rather their collaborative work in the production of 
contents. By admitting the difficulties of sharing curatorial authority in the domain of historical artworks, professionals can elaborate solutions that embed 'polyvocality', as in the case of the Laing Art Gallery, and their role would shift from being expert teachers to enablers. Furthermore, by respecting and valuing people's diverse identities and encouraging them to create a sense of place in the museum, institutions can promote social inclusion.

This paper has emphasized how valuing the socio-cultural nature of artworks can allow the formation of an inclusive and collaborative interpretation of objects. Future studies could investigate the idea of agency related to the re-interpretation of Old Masters.

Western historical art hides stories of abuse of political power, religious conflicts and discrimination between gender and races, which are also relevant in the contemporaneity. Appraising the sociocultural history of artworks could serve as a trigger to discuss these topics, meet the needs of other stakeholders within society and make analogies to the present. Hopefully, by engaging with stories that unpack relevant contemporaneous themes, visitors, professionals and collections can play proactive roles in transforming the museum into a forum for debate and create a tangible impact on people's lives. Old Masters surely embody the elitist nature of the art museum, however this paper aims to suggest that, thanks to their composite history and multiple significances, their potential to re-live in the present and shape our thinking is enormous.

\section{References}

Appleton, J. (2007). Museum for 'The People'?. In S. Watson (Ed), Museums and their Communities (pp. 114-126). New York: Routledge.

Barbieri. G. (2004). Nella mobilità del tempo. Una proposta di percorso per l'opera d'arte. Vicenza: Terra Ferma.

Bordieu. P. (1993). The Field of Cultural Production. Cambridge: Polity Press.

Collections Trust. (2009). Revisiting Museums Collections. A toolkit for capturing and sharing multiple perspectives on museums and galleries collections. Retrieved from http://www.collectionslink.org.uk/media/com_form2content/documen ts/c1 /a514/f6/revisiting_museums_toolkit-1.pdf.html

Conforti, M. (1993). History, Value and the 1990s Art Museum. Museum Management and Curatorship, 12(3), 245-255.

Conforti, M. (1995). Museums Past and Museums Present. Museum Management and Curatorship, 14(4), 339-355.

Derrida. J. (1972). La dissémination. Paris: Edition du Seuil.

Foucault. M. (1975). Surveiller et Punir: Naissance de la prison. Paris: Editions Gallimard.

Herrero. M. (2007). Irish Intellectuals and Aesthetics. The Making of a Modern Art Collections. Dublin: Irish Academic Press.

Hooper-Greenhill, E. (1988). The museum: the socio-historical articulations of knowledge and things. London: University of London.

Hooper-Greenhill. E. (1992). Museums and the Shaping of Knowledge. London: Routledge.

Hooper-Greenhill, E. (1994). Audiences: A curatorial dilemma. In E. HooperGreenhill (Ed.), The Educational Role of the Museum (pp. 262-263). New York: Routledge.

Hooper-Greenhill, E. (2000). Changing values in the Art Museum: rethinking communication and learning. International Journal of Heritage Studies, 6(1), 9-31.

Hutchison, M. (2013). 'Shared Authority' Collaboration, Curatorial Voice, and Exhibition Design in Canberra, Australia. In V. Golding \& W. Modest 
(Eds.). Museum and Communities: Curators, Collections and Collaboration (pp. 143-162). Oxford: Bloomsbury.

ICOM. (2007). Museum Definition. The Vision. Retrieved from http://icom.museum/the-vision/museum-definition/.

Iervolino, S. (2013). Museums, Migrant Communities, and Intercultural Dialogue in Italy. In V. Golding \& W. Modest (Eds.), Museum and Communities: Curators, Collections and Collaboration (pp. 113129). Oxford: Bloomsbury.

Karp, I., et al. (Eds.). (1992). Museums and Communities. The Politics of Public Culture. London: Smithsonian Institution.

Lang, C., et al. (Eds.). (2006). The Responsive Museum: Working with Audiences in the Twenty-First Century. Aldershot: Ashgate.

Mason, R. et al. (Eds.). (2013). One Voice to Many Voices? Displaying Polyvocality in an Art Gallery. In V. Golding \& W. Modest (Eds.). Museum and Communities: Curators, Collections and Collaboration (pp.163-177). Oxford: Bloomsbury.

Messenger, M. P. (Ed.). (1999). Whose Culture? The Ethics of Collecting Cultural Property. Albuquerque: University of Mexico Press.

Meszaros, C. and Others. (2011). Interpretation and the Art Museum. Between the Familiar and the Unfamiliar. In J. Fritsch (Ed.), Museum and Gallery Interpretation and Material Culture (pp. 35-50). London: Routledge.

Museums Association. Museum 2020 Discussion Paper (2012, July). $\begin{array}{llll}\text { Museum } 2020 . & \text { Retrieved }\end{array}$ http://www.museumsassociation.org/museums2020/aboutmuseums2020.

O'Brien, D. (2013). Public Value and Public Policy in Britain: prospects and perspectives. In C. Scott (Ed.), Museums and Public Value: Creating Sustainable Futures (pp. 145-156). Farnham: Ashgate.

O'Neill, M. (2006). Essentialism, adaptation and justice: Towards a new epistemology of museums. Museum Management and Curatorship, 21(2), 95-116.

O'Neill, M. (2007). Kelvingrove: Telling Stories in a Treasured Old/New museum. Curator, 50(4), 379-399.

Porter, G. (1991). Partial Truths. In G. Kavanagh (Ed.), Museum Languages: Objects and Texts (pp. 103-117). Leicester: Leicester University Press.

Rabinov, P. (Ed.). (1991). The Focault Reader: an Introduction to Foucault's Thoughts. Harmondsworth: Penguin.

Sandell. R. (2012). Museums, Society, Inequality. New York: Routledge.

Shinner. L. (2001). The Invention of Art: a Cultural History. Chicago: Univ. of Chicago Press.

Simon, N. (2010). The Participatory Museum. Santa Cruz, CA: Museum 2.0.

Stam, D. C. (2005). The informed muse: The implications of 'The New Museology' for museum practice. In G. Corsane (Ed.). Heritage, Museums and Galleries: An Introductory Reader (pp. 55-58). London, UK: Routledge.

Trodd, C. (2003). The discipline of pleasure; or, how art history looks at the art museum. Museum and Society, 1(1), 17-29.

Tucker, M. "Who's on First?" Issues of Cultural Equity in Today's Museums'. In C. Becker et al. (Eds.). Different Voices: a social, curatorial, and historical framework for change in the American Art Museum (pp. 916). New York: Association of Art Museums Directors.

Weil, S. E. (1990). The proper business of the museums: ideas or things?. In S. E. Weil (Ed.), Rethinking the Museum and Other Meditations. Washington, DC: Smithsonian Institution Press.

Weil. S. E. (1997). The Museum and the Public. Museum Management and Curatorship, 16(3), 257-271.

Weil, S. E. (2002). Making Museum Matter. London: Smithsonian Institution Press.

Whitehead. C. (2009). Museums and the Construction of Disciplines: Art and Archaeology in Nineteenth-Century Britain. London: Duckworth.

Whitehead. C. (2012). Interpreting Art in Museum and Galleries. London: Routledge.

Witcomb, A. (1997). On the Side of the Object: an Alternative Approach to Debates About Ideas, Objects and Museums. Museum Management and Curatorship, 16(4), 383-399. 


\section{Abstract}

The paper is based on research that has critically assessed developments in the display of Fine Art in the UK, in order to identify strategies that, whilst retaining the integrity of the objects' history and respecting curatorial expertise, make artworks accessible to visitors and engage the audience in the development of the exhibits. The research aims to propose frameworks of practice for museums where these artworks are interpreted according to the art historical canon, speaking an obscure language to the contemporary global audience. As a consequence, whilst the international debate is proposing participative models of museums, the gap between curatorial practices and museological debate is increasing. The paper intertwines theoretical and epistemological reflections with observations of museum practice. After the contribution of participatory museology, a downfall of the museum literature has been the lack of discussion about the position of the specialist value of artworks in the development of socially relevant displays. This resulted in artworks being largely presented from an art historical point of view. It will be discussed how, by validating objects' sociocultural history, diverse expertise within the museum workforce can be valorised and can collaborate to include new voices and develop participatory and accessible displays.

Key words: Participation, Fine Art, Interpretation, Epistemology.

\section{Resumen}

\section{Cuestionando la participación y las formas de exhibir en museos de arte}

Este ensayo se basa sobre una investigación crítica de las instalaciones de obras de arte anteriores al siglo XX en el Reino Unido, al fin de identificar las estrategias interpretativas y las prácticas curatoriales para realizar exposiciones accesibles, aun público no especialista, favoreciendo su participación en la planificación de la exposición. Al enfrentar la brecha entre las tendencias curatoriales actuales y el debate internacional a favor de un museo participativo, se pretende proponer marcos metodológicos útiles para que en los museos las obras de arte no sigan siendo interpretadas y organizadas según trillados cánones disciplinarios, inaccesibles para la moderna sociedad multicultural. El ensayo confronta reflexiones teóricas y epistemológicas con observaciones sobre la práctica actual en los museos. A pesar de las contribuciones de la museología participativa en el reconocimiento de la polisemia de los objetos, la literatura especializada a menudo ignora el rol específico que la obra de arte asume en el desarrollo de exposiciones socialmente relevantes. Aquì se sostiene que la valorización de la historia cultural y social de los objetos debe ir en paralelo con la aparición de nuevas profesionalidades, cuya colaboración con el personal existente permitirá planificar exposiciones participativas y accesibles.

Palabras clave: Participación, Bellas Artes, Interpretatión, Epistemología 